\title{
Three narratives of anthropological engagement
}

\author{
By Melania Calestani (Goldsmiths), Ioannis Kyriakakis (UCL), and Nico Tassi
} (UCL)

This article is an account of different experiences, reflections and impressions that have arisen when embarking on the process of doing anthropological research and writing a thesis. The common ground of these three narratives is that they refer to our personal engagement with anthropology, our experiences within the academic world, as well as to our restless endeavour to make sense of them. We are particularly concerned with the language, the methods, and what usually remains unsaid or is taken for granted with regard to the context of anthropological training, fieldwork and writing up. Our claim is that whereas we as anthropologists attentively take into account the context of our research, we have often failed to pay a similar kind of attention to ourselves and our academic context. We see this article as a contribution towards such study.

\author{
The thesis is a ritual of initiation ... \\ a boring, rich collection and display of data ... \\ something that must show your knowledge \\ of the principles of anthropology. \\ Theses are intellectual exercises, \\ they are not meant for reading, \\ they will lay in the dust of Senate House library. \\ Unlike books, theses should not be interesting, \\ they must be plain and bulky, in fact \\ they are the negative of books.
}

(Anonymous professional anthropologist)

\section{Learning by heart}

Nico Tassi

My interest in anthropology developed at the end of my teenage years, a time of ideological and sentimental disputes. I like to believe that my interest and passion for anthropology carried the strength and the disillusionment of certain leftist political ideals as well as of wholehearted experiences of the teenager. I recall my understanding of anthropology as imbued with a utopian support for subaltern groups, together with a curiosity of and attraction to 'otherness'. In fact, I found in anthropology something that could give direction, stability and purpose to those energies and passions that one feels unleashing during youth. Yes, there was a political motivation in my understanding of anthropology that, however, never killed the 'magic' in me, nor made me so obsessed with power as to 'fail to sense the manylevelled complexity (hence irony and forgivability) of human lives experienced at first hand' (Turner 1982:8-9).

Without even realising it, I found myself one day in a position where anthropology was not simply a juvenile passion. Anthropology had become more than an exotic game; it was a way to understand the 'unknown other' within myself and my life. My persona had become the medium, a way to 'understand other people and their 
expressions on the basis of experience and self-understanding' (Dilthey 1976:218). Unconsciously I had started practicing anthropology on my family, to understand the awkward relationship I had with my father. By doing 'fieldwork' with him I tried to smooth contrasts, tear down generational boundaries and give voice to those masculine silences that a father-son relationship often produces. Equally unconsciously I had started using anthropology to heal the scars of certain private experiences. I could find a strange relief from the scars of death and love through the beautifully sober life-histories that I liked to collect from close co-villagers.

In 1998, four years into my BA degree, I did my first intensive fieldwork in a remote indigenous community of the Bolivian Highlands. I set out with a mixture of genuine fear and excitement to study Andean religion. Six months into my fieldwork I had not learned much about Pachamama, highland shamanic practices or sacred stones whispering in the wind across the vertiginous landscape. Instead, I had become familiar with the Chinese horoscope and involved with an obscure New Age prophecy identifying the end of the world and the universal judgment with the coming of the year 2000. When I returned, I went back to Professor Sobrero and I described to him the irony of my experience. He gave me a book to read and pointed at a paragraph that read:

He wrote of them with the utmost seriousness. He gave them families, backgrounds; he treated what they said without irony ... What was missing from [the anthropologist/historian's] view was what we all lived with: the sense of the absurd, the idea of comedy, which hid from us our true position. The social depth he gave to ordinary people didn't make sense. The idea of a background - and what it contained: order and values and the possibility of striving: perfectibility - made sense only when people were truly responsible for themselves. We weren't responsible in that way. Much had been taken out of our hands. We didn't have backgrounds. We didn't have a past. For most of us the past stopped with our grandparents; beyond that was a blank. If you could look down at us from the sky you would see us as living in our little houses between the sea and the bush; and that was a kind of truth about us. We were just there, floating ... It was that idea of the absurd, never far away, that preserved us. (Naipaul 1994:79-80)

Professor Sobrero liked to speak of Vidiadhar Surajprasad Naipaul's work as the finis anthropologiae. Naipaul represented the ultimate anti-anthropological stance, somebody whose ideas and words had never been digested by scholars and politicians. And yet Sobrero, an anthropologist, handed that 'anti-anthropological' book to the inexperienced student. It was a gesture that struck me deeply. Unlike the juvenile political ideologies that were so full of passion and still somehow so stiff, anthropology had this disposition to stretch its own boundaries beyond common rational limits. Not only did anthropology seem to hold the ability to accept, value and genuinely appreciate the 'anti-anthropological', but also the maturity to recognise the 'absurdity' and the 'irony' of its own craft. Sobrero's gesture and words, articulated with the excitement of a child venturing in forbidden territory, exposed an attachment to and affection for his own work beyond the seriousness of his authoritative figure. I could see an uncompromised commitment reaching beyond the disciplinary boundaries and pedagogical rules of academia; his romantic respect for lived experiences and desires as the real source from which anthropological production takes its shape and poignancy. A year later I enrolled on a PhD course in London. 


\section{(Un)reconciled languages}

The sense of inadequacy that a country boy in London feels is never really extinguished. But the intimidation caused by this cosmopolitan and sometimes hostile city or by the refined manners of English academia was always flanked by a concealed appreciation. As the same Naipaul observes with legitimate pretension, eventually 'only a country boy could have loved the city as I did when I came to it' (Naipaul 1994:11). The most striking novelties were the informal relationships with the teachers, the almost embarrassing possibility of speaking in public or the continuous prospect of being asked your opinion. We also found new precious kinships that gave us protection and courage. It felt as if we were doing something important with an intensity, accuracy and commitment that outshone the approximate and precarious working practices of my recent past.

I had been warned about the ceremonial character of some of the local practices and seminars intended to reproduce, restate and legitimate the anthropological community, but as an aspiring anthropologist I thought I would not have any problem in tuning in with another extravagant ritual. However, the language was different. Not simply in the sense that it was foreign to me, but also because I could not grasp the code of interaction. I am not talking here of a secretively codified language, but rather of the sensation that the content of the discussion was continuously slipping away without leaving a trace, a handhold we could hook on to. It was as if that 'knowledge' had been magically uprooted from its container and now floated in the void. Under the low ceiling of that large seminar room it seemed as if the world outside and inside of us had ceased to exist. Talking in obsessive detail and anaesthetised language about practices thousands of miles distant from that seminar room probably enabled us to arrange foreign concepts in clearly marked heaps of sense and nonsense. However, it also produced the effect of alienating words from things and distancing the academia from the field rather than conveying the presence and the spirit of those more or less exotic places. There was something unnatural in these weekly displays of analytical depth and meticulousness when compared to the precariousness and improvisation of the ethnographic research they were drawing from.

Becoming a professional anthropologist appeared to require picking up that language and mimicking its related principles and manners. We needed to learn what to say, what not to say, and especially how to say it. We were serious anthropologists now, we had to suspend our southern quirks and beliefs and learn to talk the powerful language. It was as if our professional role had to be severed from our persona. I felt a bit like those shy and warm-hearted young Andean peasants approaching the cities of the Andean plateau with a mixture of trepidation and appreciation. The fearful anticipation of not understanding the language, the code and the demeanours, and the feeling of failure, inadequacy and unpreparedness for the academic world we had chosen as our future career, injected into us an anxiety to conform or at least to push ourselves to put aside our specific motivations and commitments. Like those young indigenous peasants who changed their clothes and names to disguise themselves as modern urban citizens, to avoid the contemptuous gazes or sarcastic laughter, that academic language and those practices, so powerfully neutral, perfectly balanced and tremendously precise, instilled in us almost a sense of shame, first for our coarse expressive skills, and secondly for the impartiality of our motivations, almost for an excessive personal engagement with what we did. 
I often found it grotesque but still unavoidable the way we - as students - contrived to find the most refined ways to embroider, sparkle up and eventually hide deep between or behind the words, ideas and feelings that were too mundane, scarcely elaborated. Even when I dared to ask questions during curricular activities I could not avoid feeling, in my own attitude, a kind of unnatural theatricality in the use of words. We were all trying to play the game, a strange but necessary game where nobody can afford to say what she really believes, from the bottom of her heart. When I asked a male colleague, regarding his upgrading proposal, whether he had been able to frame into words his research interests and intuitions, he sardonically replied: 'Well no, I have been too busy trying to disguise what I really feel about it.'

We perceived the beauty and the precision of that language so elaborate and rich, so free as to seem liberated of its corporal burden, and so powerfully refined by time and practice as to sound like a captivating instrument for the young apprentices. In the first book ever written in Quechua, an anonymous Quechua writer commented on the sermons of the Catholics, and expressed his appreciation for the 'wisdom and understanding' of the Catholic friars and the morality of their ideas and principles.

But maybe [those ideas] will not be able to reach deep to the heart of [Andean] people ... maybe they will just dissimulate to be good Christians for fear of the doctrine. They said 'I don't want the Father to find out that I am not a good Christian' and they still prayed the Rosary while entrusting somebody else to carry out the ancient adorations. (De Avila [1598] 1966:69)

The rigour and the moral rectitude of a discipline or doctrine, and the 'superiority' of an intimidating language, can be powerful pedagogical tools to inscribe the message in the minds of inexperienced apprentices or believers. However, learning through fear of exclusion and respect for the serious practices and language sometimes does not allow knowledge to sediment, does not allow the recipient to explore it thoroughly and to let it cling to personal experiences. It was a half-hearted process, yes, we dissimulated in order to take part in the game, to feel part of something in the loneliness of our exotic research projects, to prove to others and to ourselves that we could be good anthropologists. We put on hold dear convictions, the feeling of irony and absurdity, and we played seriously.

We felt a contradiction in this year of preparation for fieldwork, springing from our expectation - felt as a personal necessity - that we would reconcile our experiences and ideas with the life and demeanours of academia. As aspiring anthropologists we perceived ourselves as embodying the living link between the habits of thought and languages we acquired while living with 'them' and the constructs and expressive forms of 'our' anthropology departments. As anthropologists living with them, speaking their language and learning to

... represent their experience to ourselves in their way, we come as near to thinking like them without ceasing to be ourselves. Eventually, we try to represent their conceptions systematically in the logical constructs we have been brought up to use; and we hope at best thus to reconcile what can be expressed in their languages, with what can be expressed in ours. (Lienhardt 1954:96, quoted in Asad 1993:192, my emphasis)

Those of us who had already done fieldwork in familiar or in exotic places, and who carried embodied memories of the secret thoughts and the vacillating feelings of the people we had lived with, perceived a tension in our academic practices. We tended to 
make their words and ideas into interesting material to work on, rather than recognising their claim to a parity of rights and dignity with the discourse and knowledge of the discipline. Instead of working to 'reconcile the languages' we now perceived a vivid discrepancy.

We did not want to magnify the value or intrinsic rationality of other cultures or to grant them a surplus of tolerance. Maybe we wanted to say that their non-academic worlds and their knowledges have their circles and depths, just as our predominately erudite lore has. But most importantly we thought of anthropology as a concrete vehicle of dissemination of the cultural possibilities learned and lived in nonacademic circles.

\section{Fieldwork in the heart of darkness}

loannis Kyriakakis

I am partly working class and partly peasant class Greek in origin, with a previously urban middle class status (in post-World War II Greece, people changed their class status within one generation, and my parents did so), which I gave up in order to come to London and study anthropology. I followed an ordinary and simple set of incentives. I had studied political science in my youth but I did not like it. My inclinations soon turned towards narrative and performing arts. My father died suddenly from a heart attack at the age of 58 when I was 27 , and at that time I was struggling to study filmmaking in Germany, which I dropped after his death. I returned to Greece and I resumed working as a waiter to support my mother.

It was a series of dreams and nightmares that had started just a few months before my father's death that have come to mark my life course ever since. The dreams persisted and intensified after the loss and I started recording them and trying to interpret them. Gradually I started reading and rereading everything related to dreams, from psychoanalysis to biology, cognitive psychology, philosophy, neuroscience and psychiatry in order to support my interpretations. After four years of doing that I set out for a second degree in psychology, but psychology proved not to be my path. My research proposals were so broad and overtly introspective that they did not fit the spirit of today's highly specialized and objectivity-oriented modern psychology. I was an alien, and in fact I could be a subject of research myself - and as it turned out, this was indeed how I made my first contact with anthropology. Some friends introduced me to Charles Stewart, a prominent 'Greek' and dreams specialist from University College London (UCL), who at that time was researching urban perceptions of dreams in Athens. After we met he realised that I was not the kind of informant he was looking for, and as for my own concerns he suggested that I should try anthropology instead of psychology.

Three years later I found myself landing in Ghana to do my fieldwork. In the meantime I had entered the academic world of anthropology, finished my masters, acquired a scholarship for a $\mathrm{PhD}$, and completed a weird MPhil stage where I modified my topic twice. From dreams I had moved to witchcraft before starting the $\mathrm{PhD}$, but my tendency towards grand theory (I had the ambition of explaining witchcraft, as I had had the ambition of explaining dreams some years earlier) made my project 'unrealistic', and I had to move from witchcraft to religion.

I was supposed to have been trained to use the right methodology for my fieldwork context and that was all. But it was not. When I first found myself in Ghana, the shock was tremendous. I was the white man! My whiteness was the greatest feature of my 
presence there! People treated me as a white-man and nothing else. There was nothing in the 'anthropological knowledge', nothing in the 'training', nothing in the tricks of the magician-ethnographer, that had informed me of the counter-racism against the white-men and women in contemporary sub-Saharan Africa. Nobody talks about that, but this is the real context of the research and my entire fieldwork was marked by my struggle to get rid of my whiteness, which was of course impossible. Religion then emerged not as a 'research field', but as a code of communication. What I had to do, apart from surviving, was to learn to talk the same language with the people, not in linguistic terms but in conceptual terms. Otherwise neither survival nor research would have been possible.

Gradually religion, spirits, dreams, lesser gods, witches, prophets and popular theology became the code of communication. Nothing was more useful to me in that context than my peasant background, which bore many similarities with local beliefs, and this forgotten self-study on dreams before I joined the academy. I felt as if all the concepts, the terms and the techniques of the academy were useless.

One day I fell ill. It was the ninth month of my fieldwork and I had already started transforming the code of communication into real conversion to an African Christian church operating in the area (as any commonsense resident of the area would do in order to be protected from witches, from policemen asking for bribes, from the white gold-miners recruiting cheap labour, and so forth). I had for a long time been using a prayer that my aunts and uncles used to say back in Greece in order to cast away the evil eye from other persons, but this time the sickness seemed to be much more serious than the headache or the dizziness that the evil eye usually causes. I had constant diarrhoea and severe pains in my stomach. I thought I was going to die. I said to myself: 'This is witchcraft! It is not an ordinary disease!' I ran straight to my friend and informant the fetish priestess. She was laughing at me! The white man could not be afflicted. She said: 'I would know it, if it was witchcraft!' and she suggested western medicine instead of spiritual treatment! I said: 'I am sure it is witchcraft! Perhaps your god cannot trace the witch!' While we were talking a snake appeared in front of us and I told her: 'Do you see! Do you see? The snake is the witch and came here to finish me off!'

Despite my insistence on witchcraft causality and after I tried a Christian prophet who was not at home, I took seriously the fetish priestess' suggestion and I visited the doctor's surgery in the nearest town. Each time I made an effort to do something about it the pain went down, but after a while it would come back stronger. When I entered the surgery's courtyard I found at least 50 people waiting in the line before me, 90 per cent of whom were women with children. I could see the despair in their faces, the agony and the stress. No one could know what exactly each one of them was there for-malaria, HIV, cancer, common flu; this was the only surgery within 40 kilometres. I could not know from what distance all these people had travelled to reach this surgery. A nurse came to me almost immediately. She said: 'If you want to come first, come now please. The doctor will see you immediately.' I was supposed to jump the queue because I was a white man! I felt ashamed just with the thought! I said: 'No! I will wait.' After two hours the queue was the same as when I arrived. Despite the pain I went back to my room.

There the most severe crisis of diarrhoea hit me and I was certain that I would die. While in the bathroom, I tried to spell the prayer, the same one that I had used till then for other people and the evil eye. I made only two changes. Instead of other people's 
names I put my name alone, and in the place where I asked Jesus to release the person from the evil eye, I asked to be released from the bonds of witchcraft. As soon as I finished the prayer, the pain disappeared and the diarrhoea stopped. The next day I travelled to the city to buy carton milk in order to treat my stomach which had been empty for three days. The pain and the diarrhoea did not return again.

When I returned from Africa I had to write up my thesis. The only thing I had to do was to prove that I had used the right methodological tools in order to produce a presentable amount of data informed by the relevant literature on my topic. In comparison with my experiences in the field, this was too little! And in fact it was, and it is, too hard to write precisely because it is too little. I was advised to do this now and leave the rest of my material for later. However, my most valuable experiences as well as my most valuable tools of survival and communication did not find any space within that format. And in the last instance, what would be my contribution to anthropological knowledge if not those experiences and those tools?

In my case, religion served as a code of communication and not merely as a subject of study. In that sense I came very close to the way that my informants see and practice religion. I thought that this was the original aim of anthropological knowledge, but surprisingly no one cared about that. Instead, what I had to talk about in my thesis was where I place my study within the already existing theoretical framework of religion in Africa. My experience during my fieldwork was a path of knowledge, though it was certainly not an orthodox path. However, I would never have come that close to an understanding of religion if I had only used interviews, elicited life histories and observed the rites as an outsider. This experience urged me to consider whether our taught methods and writing skills in anthropology really lead us to a better understanding of the people we live with in the field, or whether they lead us only to a reproduction of pre-existing ideas.

\section{Between field and writing up}

Melania Calestani

As Nico and Ioannis have both emphasised, doing a $\mathrm{PhD}$ is a very emotional process. Yet there is a tendency in academia to silence this specific aspect, instead defining the $\mathrm{PhD}$ process as a mere intellectual exercise. The preparation for fieldwork and what follows after it indicate that the dominant ideology of 'the ivory tower' still encourages a neutral posture in the professional anthropologist, who in theory should deny any kind of emotional attachment to his/her informants, as well as show a certain verbal confidence at any stage of the $\mathrm{PhD}$ or in any moment of difficulty, denying his/her emotive nature.

Confidence and a natural use of this denial are taught during the MPhil, are difficult to keep during fieldwork, and are proposed again as essential ingredients when embarking on the translation of local life into academic language and theory. However, as Nico and Ioannis' narratives have also shown, this stands in contrast to our experiences, and it undergirds the existence of a certain tension between what we feel and what we are supposed to write. We could passively accept this academic style, but we are moved by an urgency to discuss certain issues, and to explore new possibilities and opportunities.

Some might argue that our working class backgrounds had an impact on this unusual position, as well as our Mediterranean origins. Yet I think that we are today pushed by something deeper that has developed in us through our life experiences in the field, 
that is to say, that level of empathy we felt towards the people we lived with. This had a strong impact on the way fieldwork has changed us and has shaped our approach toward writing and anthropology. The experiences and emotions from the field did not come to an end when we returned to the university, but have come to outline our theoretical and political stance, our epistemological positioning in academia, and constitute the forces guiding our inspiration and dedication to the discipline.

It is with nostalgia that I remember the last days of my fieldwork. After 12 months of intense research in rural and urban Bolivia, it was time to go back to London to begin the last stage of my $\mathrm{PhD}$. A few days before my plane was supposed to take off from the airport of El Alto, I received presents and invitations for meals and different farewell parties. I had a busy schedule, divided between my two field sites, a village in the highlands and a neighbourhood in one of the highest cities in the world, also considered the hotbed of Latin American social protests. If someone had asked me if I were happy to leave El Alto and the Andes, I would have answered no.

When I entered the modern airport building, I felt uneasy, as if it was the first time I was travelling. For a moment I wanted to run out and breathe the fresh air of the altiplano, but I didn't and went on to do my check-in. Suddenly, among tourists and airport staff, I saw some familiar features. Sixteen people from the neighbourhood where I lived and carried out research were there in front of me.

They were the ones with whom I had shared moments of sorrow and laughter for a year. We had danced under the sky of the Southern Hemisphere at night, we had eaten from the same dish and drunk from the same glass during specific celebrations, and we had worked together in the market. We had sometimes disagreed with each other, discussed and fought in the interaction of everyday life. It had not all been easy, but I had felt at home with them. They had become my world for a year: the ones I struggled with, but also the ones who prepared hot chocolate on my birthday and refused my rent despite their need for cash. They, the inhabitants of a Latin American shantytown, worked hard to provide a better future for their children, had a strong faith in God and in the power of social protests to turn the world upside down, and accepted me, a gringita, under their roofs 'in good and in bad fortune'.

They looked out of place in the airport with their faces burnt by the sun and their dusty shoes. I felt a tightening in my stomach, knowing how much they would have had to save to come to say goodbye to me. I tried to offer them some money for their expenses, but they refused with the same stubborn dignity they had showed in the past. While I was hugging each one of them the Aymara way, I began to cry and didn't stop until I arrived in Santiago in Chile, where I stayed for two days while waiting for my flight back to Europe. In Santiago I began to write my diary.

At that stage writing was a necessity for me rather than an obligation; it represented a means of canalising my emotions, and a way of overcoming my nostalgia for the place and the people I had departed from. Back in Italy, since primary school, I had always been pushed by my different teachers to engage emotionally with my written assignments. And there I was, some years later, trying to represent on paper the reality I had experienced for one year, so that I could pin down that outside world that had melted away when I left Bolivia. Colours, smells, tastes, feelings, people, different lights and shadows at certain moments of the day, births, deaths, diseases, celebrations, earth, sky, and their inevitable changes. Quite simply, this had been my life in the Andes, something that had become part of my own identity, history and memory. 
In the process of writing in Santiago, I had the impression that words were not empty signs, but that they carried a deeper meaning, a sort of narrative, encapsulating vital energy and becoming live entities, like the Achachilas or the statues representing the Saints and other spiritual forces on the Bolivian plateau. They embodied beliefs and cosmological orders, inspired and generated by that complex tangible or intangible world (depending on one's perspective), where everything was a cuestion de fè, a matter of faith. Yet they were also the product of my personal interaction with the people I had lived with for one year. The words spoke of our peculiar stories, and how these stories were connected and interconnected, giving birth to our common account or encounter. I wrote it in Italian and Spanish, and I imagined that I was writing for both my informants and myself. It was a passionate and romantic kind of writing.

\title{
Welcome back!
}

I arrived back in London on a rainy evening. It was the 9th of November 2004. I went straight to the flat that was going to be my house for the next two years. My flatmate was there, waiting for me. I had to jump from Spanish to English. That evening it was difficult to fall asleep. The flat was like an oven-or at least I felt as if I was in an oven. It was too hot. I had been used to living at $4,000 \mathrm{~m}$ altitude with no heating, not even when I was taking a shower. In London the toilet was right next to my bedroom, which was a real luxury, considering that in Bolivia I had to go out in the fields, sometimes even in the middle of the night.

The next day I visited the anthropology department at the university. I was invited to attend the writing up seminar, so that I could meet with other PhD students and exchange ideas on fieldwork and writing. Soon after the Christmas holidays, I was asked to present a piece of writing. My paper was about my experiences with traditional shamans, and it intended to take the reader through the same process of discovery that I had gone through in order to understand their knowledge of the occult world. This was the beginning:

\begin{abstract}
Until I went to Bolivia, I never thought of luck as playing an important role in my life. Sometimes I found myself speaking about it, while I was talking with friends, underlining positive events that had shaken our lives. However, I had never perceived it as an important force shaping my existence and influencing it. Luck, for me, was not a condition or a state I could change or modify, or even something relevant to talk about. I might refer to lucky hints or moments, but without making a great deal out of it. In other words, luck was not one of my priorities or something that could influence my life or that I could personally influence through my behaviour. Fieldwork in Bolivia showed me a different perspective, an idea or a conceptualisation of luck that goes far beyond my initial understanding of it. Aymara people believe that luck can be controlled and changed by treating the spirits better. It can be bought and acquired by asking for protection from the spiritual forces living in the altiplano. Luck is inextricably connected with ideas of protection, destiny control and future aspirations.
\end{abstract}

This was followed by a description of how I got to know some traditional shamans, including autobiographical notes on different events that had allowed me to increase my understanding of that world. After reading it, some $\mathrm{PhD}$ colleagues accused me of engaging with travel writing, adding that this was not real anthropology and that it lacked neutrality and objectivity. I felt the presence of the all-powerful ideology of academia in their words. They, brilliant students with top marks, advised me to detach 
myself from my writing. I left the room of the writing up seminar feeling down and upset and wondering what I should do. After a night of reflections, I tried to adopt the new suggested style, and contemplated the option of removing my personal experiences from the text or conveying them in 'a more academic style'.

It was an extremely difficult and painful process, and the resulting text was so impersonal that it could have been written by anyone. It lacked my point of view, my life experience, my emotions toward people and events, and resulted in a very dry account interrupted by a summary of previous literature. I felt guilty not only toward myself, but also toward those people who came to the airport to say goodbye. Was that all I could say about our relationship? Where did our encounter go?

There was no communal account, and no exchange. The vital energy I had found in my words in Santiago had left the text for good. It lacked the texture of everyday interaction, which is so fundamental, in my view, for providing an idea of the background against which the research took place. As a result, everything seemed 'anaesthetised', as Nico and Ioannis would also say; a reflection of the interaction I was having with the world of academia, a world of competition and politics. In a way I was conducting fieldwork a second time, once back from the field, in 'the ivory tower'. On more than one occasion I felt isolated, thinking about the emotional commitment and attachment to my informants in Bolivia.

After a while I decided that I could not let academia influence my representation, memories and attachment to the Andes. I had to convey at least some emotions. It was then that I began to think of how I could combine that outside world that I had personally experienced with the academic ideology. Was it actually possible to create a text that enabled continuity between life and theory, between the texture of everyday existence that strongly affected my perception of the world and the atmosphere of anthropology departments? For the first time, I started to rationalise the process of writing, a process that was usually characterised by a more spontaneous impulse in my case.

I thought of writing as a weaving process, and the Andean world provided a model of inspiration: differently coloured strands form a unique picture, producing a piece of cloth that conveys collective and individual memory, like the Andean aguayos. Aguayos are usually used by Aymara women for carrying their goods and babies, but they are also representative of the community's memory. Each community has its own specific design with symbols and stories, each community writes its own history through weaving. And I too weaved my experience with that of my informants, trying to add the theory as well. My aim was to avoid the radical break often reproduced by professional jargon between writing up and ethnographic experience, instead emphasising the emotional aspects of doing fieldwork through my own narrative.

Some colleagues were sympathetic to this approach, and others disliked it. In the daily struggles for the advancement of analytical knowledge, there are as many nuances as there are individuals, but no one can deny that the academy inexorably shapes our writing, especially when it comes to the completion of PhDs. As the anonymous professional anthropologist quoted at the beginning of this article said, a thesis is 'a boring, rich collection and display of data ... theses should not be interesting, they must be plain and bulky, in fact they are the negative of books'. Hopefully, this is not always the case. I still think that analytical writing can trigger a more creative and original approach, where the anthropologist's emotional nature is not completely 
removed. However, this requires a certain level of compromise, a balance between different writing styles and audiences.

In my discussions with Nico and Ioannis, I started out by asserting that I did not strike compromises with the academy, and that I managed to write everything I felt in my thesis. Today, reflecting carefully on it, I realise that this is partially true. Colleagues and friends, I have to admit that I have compromised as well, and that my writing has been filtered and re-filtered, giving only a partial account of my stance, creating something that is definitely different from the spontaneous words of Santiago.

\section{Conclusions}

These are three different stories, different experiences and different ideas. Three stories run off. What we believe unites them is a feeling of unexpressed complicity. The anthropology we describe and try to practise, the writing through which we struggle to articulate our worlds, carry a personal urgency and necessity. Our teacher talked of the thesis as a ritual of initiation to access the professional guild, a harmless intellectual exercise. Not so innocuous, though. Writing up a thesis carries its moral and sentimental costs. You can mention the resentful competition, or you can mention the mechanised and self-humbling task of producing a disciplined and docile work that can be useful for the same academy but also neglectful of your own will and the need to tell another story.

Telling another story is not easy. Sometimes we run out of money and we have to finish as soon as possible. Sometimes we simply feel vulnerable and isolated in our research and we try to use our writing to please at least our supervisors or examiners. But sometimes that same love for what we do gives us the strength to try to weave together those worlds that seem to stand apart; to ensure that our works are not just exercises in style, but rather demonstrations of the urgency and necessity of our experiences.

\section{References}

Asad, T. 1993. The concept of cultural translation in British social anthropology. In his Genealogies of Religion: Discipline and Reasons of Power in Christianity and Islam, 171-199. Baltimore and London: The John Hopkins University Press.

De Avila, F. [1598] 1966. Dioses y Hombres de Huarochiri [Men and Gods of Huarochiri] (ed.) José María Arguedas. Lima: Museo Nacional de Historia.

Dilthey, W. 1976. Selected Writings (ed.) H.P. Rickman. Cambridge: Cambridge University Press.

Lienhardt, G. 1954. Modes of thought. In The Institutions of Primitive Society (eds.) E.E. Evans-Pritchard et al., 95-107. Oxford: Basil Blackwell.

Naipaul, V.S. 1994. A Way in the World: A Sequence. London: Heinemann.

Turner, V. 1982. From Ritual to Theatre: The Human Seriousness of Play. New York: Performing Arts Journal Publications. 


\section{About the authors}

Melania Calestani carried out research in Bolivia and Western Samoa. Her main interests include issues related to well-being, faith and morality. She is currently a research associate at Durham University, collaborating on the project The Waste of the World. She can be contacted at mellycalle@yahoo.co.uk

Ioannis Kyriakakis has recently finished writing up his thesis on Christian pluralism in Ghana, and he is particularly interested in issues of religion, magic, cosmology and political economy. He can be contacted at ioannis_kyriakakis@yahoo.co.uk

Nico Tassi is currently working on his $\mathrm{PhD}$ in Anthropology at University College London (UCL). He conducted fieldwork with Andean indigenous and mestizo settlers in La Paz, Bolivia's capital city, and his research addresses Andean representations with a particular focus on their aesthetic and cosmological qualities. His other interests include epistemology and anthropology, religion and ritual, Andean images and literature. He can be contacted at altoplanico@googlemail.com 